\title{
High-frequency coastal upwelling events influence Octopus vulgaris larval dynamics on the NW Iberian shelf
}

\author{
Jaime Otero*, Xosé Antón Álvarez-Salgado, Ángel F. González, Miguel Gilcoto, \\ Ángel Guerra
}

CSIC Instituto de Investigaciones Marinas, Eduardo Cabello 6, 36208 Vigo, Spain

\begin{abstract}
Planktonic larval dispersal affects the structure, management, and conservation of many fish and coastal invertebrate populations. The dynamics in coastal upwelling areas favour transport of larvae to the open ocean during upwelling episodes, and concentration of larvae in coastal waters under upwelling relaxation or downwelling conditions. Recent work provides evidence that pelagic larval stages in upwelling areas are influenced by specific larval behaviour, biogeography, and life history parameters among others. Nevertheless, very few of these studies have addressed these findings quantitatively. Here, we present a general approach for assessing the influence of high-frequency upwelling events on Octopus vulgaris planktonic larvae. Specifically, we analyse the rates of change in abundance and biomass of the $O$. vulgaris early larval phase in the NW Iberian coast, where upwelling events occur with a frequency of 10 to $20 \mathrm{~d}$ from April to September. Our analysis indicates that the increase in larval abundance and biomass is significantly correlated with the simultaneous decrease of water column integrated nitrate, ammonium and chlorophyll levels. These conditions occur during the early stage of the relaxation phase of coastal upwelling events, when nutrient salts are consumed to produce biogenic matter, which is retained in the system and transferred through the food web.
\end{abstract}

KEY WORDS: Larvae $\cdot$ Relaxation $\cdot$ Nutrients $\cdot$ Chlorophyll $\cdot$ NW Spain

Resale or republication not permitted without written consent of the publisher

\section{INTRODUCTION}

Coastal upwelling areas are fertilised by cold and nutrient-rich oceanic waters from 150 to $200 \mathrm{~m}$ depth in response to alongshore winds of variable intensity and persistence, depending on the latitude and the time of the year (Wooster et al. 1976). As a result of upwelled nutrients enhancing phytoplankton growth, coastal upwelling areas are among the most productive marine ecosystems and support most of the large fisheries (Pauly \& Christensen 1995). Coastal areas commonly experience shifts in their environmental conditions that may alter the entire food web (e.g. Barth et al. 2007). Specifically, these shifts play a major role in controlling population dynamics in near-shore communities, mainly across taxa with pelagic larval stages, through effects on (1) the dispersal and transport of these early-life phases and subsequently on (2) the variation in the supply of settling stages that ultimately define recruitment success (see review by Queiroga et al. 2007).

Many studies have examined the influence of coastal oceanography on meroplanktonic organisms with 'complex life cycles' (sensu Roughgarden et al. 1988). On the one hand, these studies consider that planktonic phases are transported to the open ocean during upwelling episodes, thus reducing settlement and recruitment (e.g. Connolly et al. 2001). On the other hand, the larvae are transported shoreward during downwelling episodes, thus, favouring recruitment (e.g. Farrell et al. 1991). These studies assume that larval phases behave like passive particles being swept 
offshore (onshore) during upwelling (downwelling) periods, given that swimming speeds are much lower than flow rates in the Ekman layer. However, recent work shows that larval behaviour (e.g. diel vertical migrations) plays an important role in controlling across-shore transport, and suggest that upwelling areas could be retentive rather than dispersive environments for certain species such as Carcinus maenas in the Iberian upwelling system (Marta-Almeida et al. 2006) or Concholepas concholepas in the Iberian (Marta-Almeida et al. 2006) and Chilean (Poulin et al. 2002) upwelling systems. Thus, transport, supply and settlement of invertebrate larvae will depend on a dynamic interplay between life history attributes, pelagic larval phase behaviour, and environmental conditions (Shanks \& Brink 2005, Yannicelli et al. 2006, Bradbury et al. 2008).

Galicia (Fig. 1) is at the northern boundary of the Iberian upwelling system. Coastal winds at these latitudes $\left(42^{\circ}\right.$ to $\left.44^{\circ} \mathrm{N}\right)$ are seasonal; northerly winds prevail from March-April to September-October, promoting coastal upwelling, and southerly winds predominate the rest of the year. However, $>70 \%$ of the total variability in coastal winds occurs in periods of less than $1 \mathrm{mo}$, so that the upwelling season appears as a succession of wind-stress episodes separated by calm episodes, with a frequency of 10 to $20 \mathrm{~d}$ (ÁlvarezSalgado et al. 2003), similar to other coastal upwelling systems at comparable latitudes (Hill et al. 1998). The
Ría de Vigo (Fig. 1) is a large coastal embayment that acts as an extension of the continental shelf during the upwelling season when continental runoff is scarce. The 2D positive residual circulation pattern (ingoing bottom current/outgoing surface current) responds to coastal winds at time scales ranging from a few hours to $2 \mathrm{~d}$ (Piedracoba et al. 2005). During the downwelling season, when continental runoff is high, the inner ría circulates as a positive estuary and the circulation of the outer ría reverses (outgoing bottom current/ingoing surface current) in response to the prevailing southerly winds (Álvarez-Salgado et al. 2009). Specific studies on the effects of upwelling and associated residual circulation on larval phases in Galician waters are lacking (but see González et al. 2005). Much more effort has been put into studying upwelling and tidal effects on several species in neighbouring areas, particularly Portugal (e.g. Sardina pilchardus: Santos et al. 2004, Carcinus maenas: Amaral et al. 2007, cirripede cyprid larvae: dos Santos et al. 2007).

In this work we attempt to quantify the effects of the wind stress/relaxation cycles induced in coastal upwelling areas on the changes in abundance and biomass of the Octopus vulgaris larval phase over a crossshelf section off the Ría de Vigo (Fig. 1). The reproductive cycle of $O$. vulgaris in Galician waters appears to be tuned to the seasonality of upwelling. Spawning peaks in spring (Otero et al. 2007, Fig. 2a), embryonic development takes up to $4 \mathrm{mo}$, depending on water

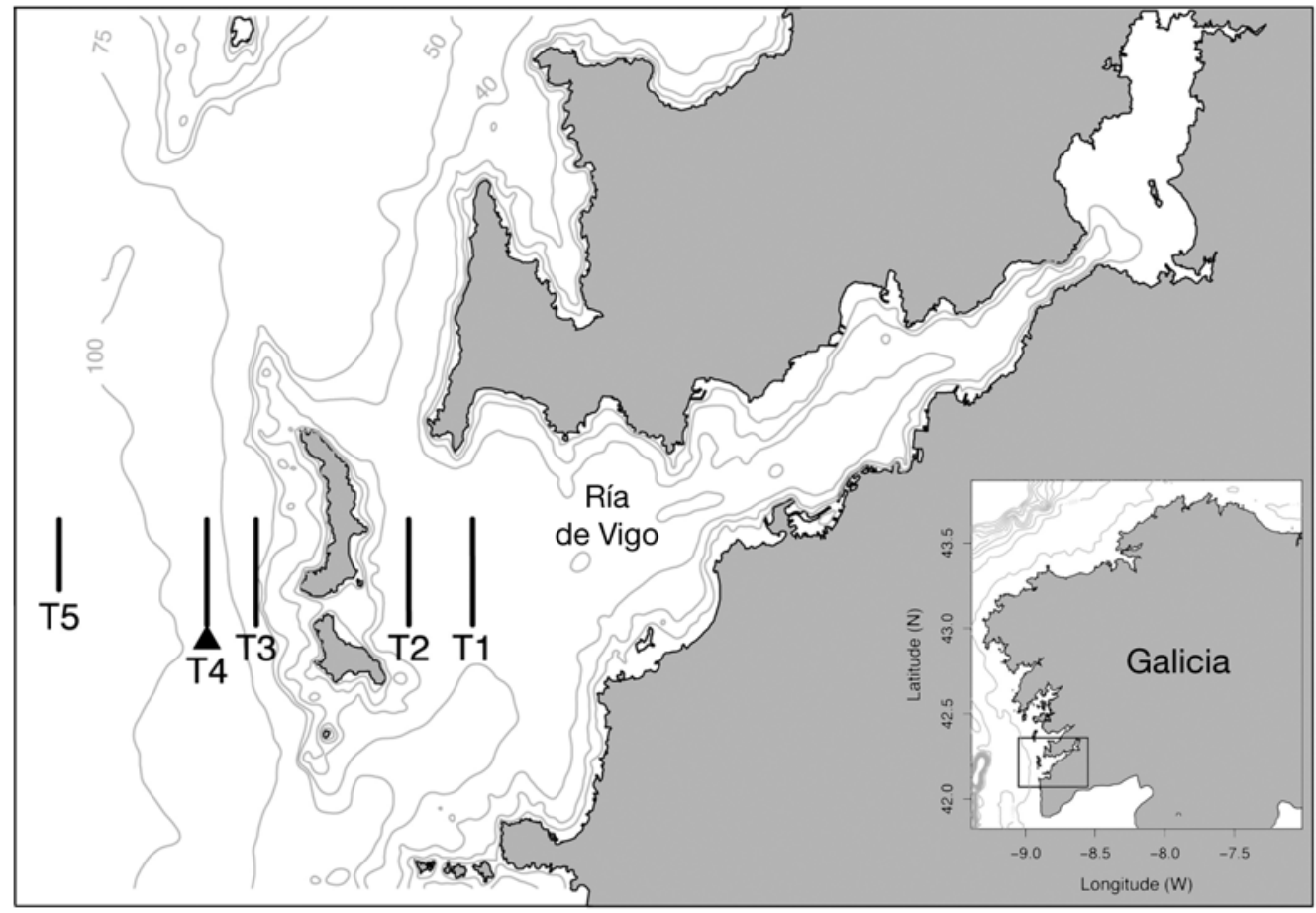

Fig. 1. Galicia, NW Spain. Ría de Vigo showing the sampling points. T1 to T5: plankton transects; ( $\mathbf{\Delta})$ rosette sampler station. Note that T1 was not sampled in 2004 and 2005 and T5 was not sampled in 2003 


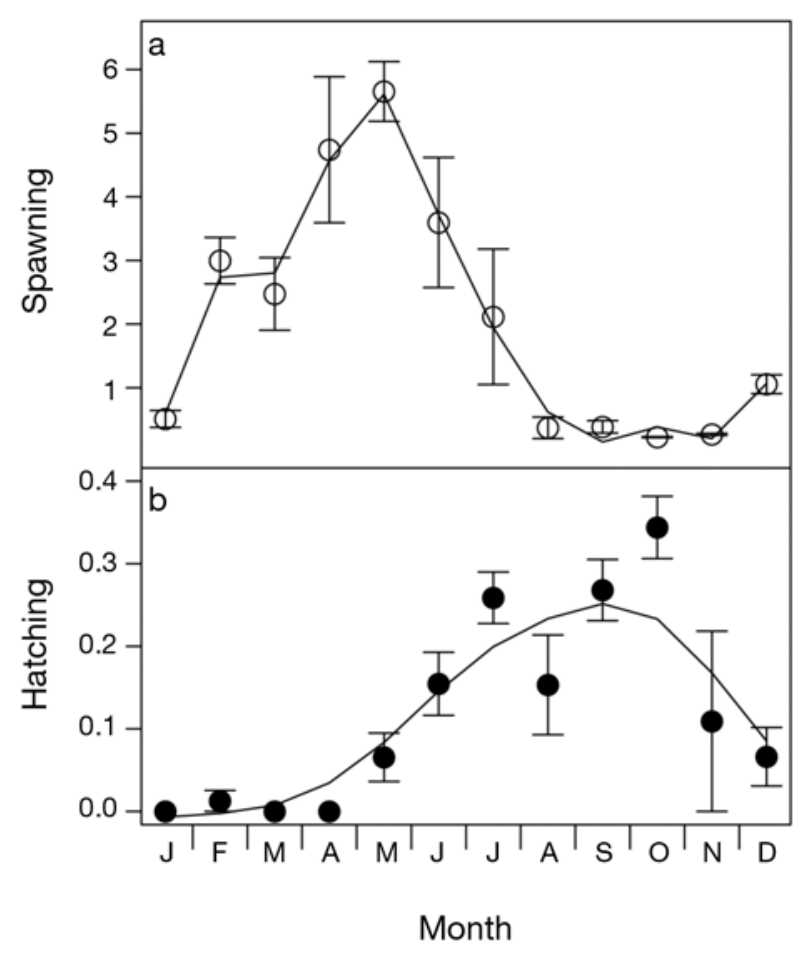

Fig. 2. Octopus vulgaris. Average (a) spawning and (b) hatching cycles in Galician waters. Spawning was measured by the gonadosomatic index of females (unitless) using data from Otero et al. (2007). Hatching was measured by the larval abundance $(x)$ standardised to the number of larvae per $10^{3} \mathrm{~m}^{3}$ and $\log x+1$ transformed using data from González et al. (2005) and this study. The trend is shown with the predicted curve from a generalised additive model. Error bars $=\mathrm{SE}$

temperature (Katsanevakis \& Verriopoulos 2006), and hatching peaks at the end of summer or the beginning of autumn (Fig. 2b). Octopus larvae (actually termed paralarvae, following Young \& Harman 1988, but we use 'larvae' for simplicity) are estimated to stay in the water column up to 4 mo (dependent on water temperature; Katsanevakis \& Verriopoulos 2006). Previous studies suggest a link between octopus pelagic larval abundance and upwelling in Galician waters (Rocha et al. 1999, González et al. 2005, Moreno et al. 2009); and Otero (2006) provides evidence that early stages are mostly present near the sea bottom during the day and near the surface during the night, as has also been described in Japanese waters (Takeda 1990, Sakaguchi et al. 1999). Recruitment is considered to occur during the following summer (Arnáiz 2006), and the bulk of that cohort will be harvested the following year. Based on this framework, Otero et al. (2008) hypothesise that in Galician waters, environmental factors related to upwelling have a major effect on the survival of the planktonic stages of $O$. vulgaris, setting the year class strength and largely driving interannual changes in yield.
The objective of this study was to examine the influence of high-frequency coastal upwelling events on dynamics in octopus hatchlings in near shore waters. Most of the previous quantitative studies relating larval abundance and oceanography have been conducted using organisms which posses a small-sized and abundant planktonic phase (e.g. barnacles and crabs), attempting to correlate abundance with, for instance, temperature, salinity and wind-stress; or comparing abundances among contrasting previously defined oceanographic conditions. In this work, we relate the rates of change in larval abundance between surveys with the rates of change in the hydrographic and chemical conditions of the water column. Our unique purpose in using this approach was to test the possibility to assess the increase (or decrease) of larval abundance and biomass associated with a specific oceanographic situation (spin-up or spin-down phases of upwelling or downwelling episodes) defined from the shifts in the hydrography of the water column, associated with the wind stress/relaxation cycles.

\section{MATERIAL AND METHODS}

Sampling regime. Surveys $(n=47$; daytime $=43$, nighttime $=4$ ) to collect plankton and hydrographic samples were conducted onboard RV 'Mytilus' from 2003 to 2005 (Fig. 1). In 2003, we sampled from February to December, whereas in 2004 and 2005 sampling was restricted to May to October (Table 1).

Plankton samples. Zooplankton samples were collected from 4 transects parallel to the coast: T1, T2, T3 and T4 with average bottom depths of 36, 26, 68 and $85 \mathrm{~m}$, respectively (Fig. 1). During the monthly surveys of 2003, larvae were not captured in T1, thus a deeper transect (T5, $110 \mathrm{~m}$ depth) was substituted for T1 in 2004 and 2005 (Fig. 1). Samples were taken by towing nearbottom and at the surface a $750 \mathrm{~mm}$ diameter bongo net of $375 \mu \mathrm{m}$ mesh. At a ship speed of 2 knots, the bongo net was lowered and stabilised near the bottom for $15 \mathrm{~min}$ and subsequently hauled up at $0.5 \mathrm{~m} \mathrm{~s}^{-1}$. Then, it was cleaned and towed in the surface layer for another $15 \mathrm{~min}$. The bongo net was equipped with a mechanical meter to record the water flow. Plankton samples were fixed onboard with $4 \%$ buffered formalin for $24 \mathrm{~h}$, and preserved in $70 \%$ alcohol. Larvae were separated and later classified with reference to Sweeney et al. (1992) and to a larvae reference collection previously obtained from laboratory-reared specimens. The data were standardised to the number of larvae per $10^{3} \mathrm{~m}^{3}$ and log-transformed before further analyses. A constant (+1) was added to include zero data.

Each octopus larva was placed on blotting paper to remove alcohol from the mantle cavity and body 
Table 1. Values in each survey of the selected environmental covariates that entered the optimal model. See 'Results Environmental variables' for abbreviations. Surveys 2 $(27 / 03 / 03)$ and $5(05 / 05 / 03)$ were not used due to problems with the rosette sampler; Surveys 24 (15/09/04), 30 (21/10/04), $34(18 / 07 / 05)$ and $41(26 / 09 / 05)$ were performed during the night and are not included in this study

\begin{tabular}{|c|c|c|c|c|}
\hline Survey & $\begin{array}{c}\text { Date } \\
\text { (dd/mm/yy) }\end{array}$ & $\begin{array}{c}\mathrm{NO}_{3 i} \\
\left(\mu \mathrm{mol} \mathrm{kg}{ }^{-1}\right)\end{array}$ & $\begin{array}{c}\mathrm{NH}_{4 i} \\
\left(\mu \mathrm{mol} \mathrm{kg}{ }^{-1}\right)\end{array}$ & $\begin{array}{c}\mathrm{Chl}_{i} \\
\left(\mu \mathrm{Kg} \mathrm{l}^{-1}\right)\end{array}$ \\
\hline 1 & $13 / 02 / 03$ & 7.21 & 0.48 & 0.75 \\
\hline 3 & $10 / 04 / 03$ & 3.25 & 0.09 & 2.15 \\
\hline 4 & $21 / 04 / 03$ & 2.19 & 0.97 & 1.07 \\
\hline 6 & $26 / 05 / 03$ & 7.82 & 0.33 & 1.21 \\
\hline 7 & 05/06/03 & 5.34 & 0.81 & 2.30 \\
\hline 8 & 02/07/03 & 5.40 & 1.05 & 1.38 \\
\hline 9 & $21 / 07 / 03$ & 8.32 & 0.36 & 3.99 \\
\hline 10 & $19 / 08 / 03$ & 7.30 & 0.28 & 1.10 \\
\hline 11 & 04/09/03 & 6.63 & 0.72 & 1.08 \\
\hline 12 & $25 / 09 / 03$ & 7.22 & 0.46 & 0.57 \\
\hline 13 & 08/10/03 & 8.44 & 0.54 & 0.27 \\
\hline 14 & $23 / 10 / 03$ & 5.73 & 0.36 & 1.61 \\
\hline 15 & $11 / 12 / 03$ & 5.73 & 0.25 & 0.50 \\
\hline 16 & $27 / 05 / 04$ & 5.40 & 0.52 & 2.52 \\
\hline 17 & $10 / 06 / 04$ & 6.56 & 0.65 & 2.12 \\
\hline 18 & 17/06/04 & 5.98 & 0.37 & 0.78 \\
\hline 19 & 23/06/04 & 4.41 & 0.34 & 2.12 \\
\hline 20 & 02/07/04 & 5.02 & 0.38 & 1.73 \\
\hline 21 & 09/07/04 & 9.60 & 0.21 & 1.31 \\
\hline 22 & $16 / 07 / 04$ & 9.81 & 0.24 & 2.05 \\
\hline 23 & 08/09/04 & 7.71 & 1.25 & 3.50 \\
\hline 25 & $15 / 09 / 04$ & 9.43 & 0.81 & 0.77 \\
\hline 26 & $22 / 09 / 04$ & 10.38 & 0.22 & 1.37 \\
\hline 27 & 08/10/04 & 9.43 & 0.10 & 0.89 \\
\hline 28 & 15/10/04 & 4.98 & 1.00 & 0.45 \\
\hline 29 & $21 / 10 / 04$ & 2.58 & 1.22 & 1.31 \\
\hline 31 & $12 / 07 / 05$ & 5.44 & 0.25 & 9.45 \\
\hline 32 & $14 / 07 / 05$ & 9.35 & 0.21 & 4.76 \\
\hline 33 & $18 / 07 / 05$ & 6.48 & 0.26 & 1.76 \\
\hline 35 & 21/07/05 & 7.88 & 0.31 & 3.32 \\
\hline 36 & 26/07/05 & 6.49 & 0.75 & 1.86 \\
\hline 37 & $28 / 07 / 05$ & 3.89 & 1.68 & 2.31 \\
\hline 38 & $20 / 09 / 05$ & 8.50 & 0.30 & 3.38 \\
\hline 39 & $22 / 09 / 05$ & 8.62 & 0.66 & 2.63 \\
\hline 40 & $26 / 09 / 05$ & 6.89 & 0.44 & 2.19 \\
\hline 42 & 29/09/05 & 9.03 & 0.51 & 1.11 \\
\hline 43 & 04/10/05 & 10.06 & 0.61 & 2.02 \\
\hline 44 & 06/10/05 & 11.77 & 0.30 & 0.54 \\
\hline 45 & $11 / 10 / 05$ & 11.21 & 0.43 & 1.88 \\
\hline 46 & 13/10/05 & 5.95 & 0.69 & 1.97 \\
\hline
\end{tabular}

weight (BW) determined on a Sartorious MC-210-P microbalance to the nearest $0.01 \mathrm{mg}$. The dorsal mantle length (DML) and mantle width (MW) of each larva was recorded to the nearest $0.001 \mu \mathrm{m}$ using the software Eclipsenet 1.20 (Laboratory Imaging s.r.o. for Nikon B.V.) on a PC (Asus) connected to a digital camera (Nikon DXM1200F) on a dissecting microscope (Nikon SMZ800). Individuals deformed during collection (e.g. those with damaged or inverted mantles) were not measured.

Hydrographic samples. A rosette sampler with twelve 101 Niskin bottles was deployed at the southern end of Transect T4 (85 m depth; Fig. 1). Salinity and temperature were recorded with a Seabird 9/11 CTD probe attached to the sampler, also equipped with a WetLabs ECO FL fluorometer and a Seatech transmissometer. Conductivity measurements were converted into practical salinity scale values with the equation of UNESCO (1986). Seawater samples for the analysis of dissolved oxygen, nutrient salts, and chlorophyll were taken from 5, 15, 30, 50, 70 and $80 \mathrm{~m}$.

To analyse dissolved oxygen $\left(\mathrm{O}_{2}\right)$ water was collected in calibrated $110 \mathrm{ml}$ glass flasks. After fixation, they were kept in the dark until analysis in the laboratory $24 \mathrm{~h}$ later. $\mathrm{O}_{2}$ was determined by Winkler potentiometric endpoint titration using a Titrino 720 analyser

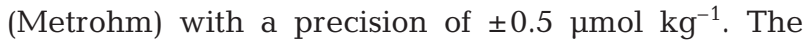
apparent oxygen utilisation, $\mathrm{AOU}=\mathrm{O}_{2}$ sat $-\mathrm{O}_{2}$, was calculated using the algorithm proposed by Benson \& Krause (UNESCO 1986) for oxygen saturation $\left(\mathrm{O}_{2}\right.$ sat).

Water samples for nutrient salt analysis were collected in $50 \mathrm{ml}$ polyethylene bottles. They were frozen $\left(-20^{\circ} \mathrm{C}\right)$ until segmented flow analysis in the laboratory. The precision is $\pm 0.02 \mu \mathrm{mol} \mathrm{kg}{ }^{-1}$ for nitrite $\left(\mathrm{NO}_{2}^{-}\right)$, $\pm 0.1 \mu \mathrm{mol} \mathrm{kg}{ }^{-1}$ for nitrate $\left(\mathrm{NO}_{3}^{-}\right), \pm 0.05 \mu \mathrm{mol} \mathrm{kg}^{-1}$ for ammonium $\left(\mathrm{NH}_{4}^{+}\right), \pm 0.02 \mu \mathrm{mol} \mathrm{\textrm {kg } ^ { - 1 }}$ for phosphate $\left(\mathrm{HPO}_{4}{ }^{2-}\right)$ and $\pm 0.05 \mu \mathrm{mol} \mathrm{kg}{ }^{-1}$ for silicate $\left(\mathrm{SiO}_{4} \mathrm{H}_{4}\right)$ (Álvarez-Salgado et al. 2006).

The chlorophyll-a (chl a) of 100 to $200 \mathrm{ml}$ of each water sample was retained on a GF/F filter that was immediately frozen $\left(-20^{\circ} \mathrm{C}\right)$ until analysis in the laboratory. Chl a concentration was determined with a Turner Designs 10000R fluorometer after 90\% acetone extraction (Yentsch \& Menzel 1963). The precision is $\pm 0.05 \mu \mathrm{g} \mathrm{l^{-1 }}$.

Statistical analysis. The purpose of this study was to evaluate the changes in larval abundance and biomass arising from shifts in the hydrography of the water column. We tested different generalised linear models built up considering the pairs of surveys separated $\leq 20 \mathrm{~d}$, given that upwelling episodes, separated by wind calms, occur with a frequency of 10 to $20 \mathrm{~d}$ in this area (see 'Introduction'). Therefore, we computed the rate of change in average larval abundance $(A)$ and biomass $(B)$ between surveys separated by up to $20 \mathrm{~d}$ as response variables. The same rates of change between surveys were computed for the independent selected hydrographic and chemical covariates as follows:

(1) The rate of change in average larval abundance was computed gathering all stations and strata sampled during daylight surveys, i.e. $\Delta A / \Delta t$. The same approach was used to compute the rate of change in average larval biomass, $B$, i.e. $\Delta B / \Delta t$. Two biomass variables were estimated, $B_{1}=A_{i} \times \mathrm{BW}_{i}$, where $A_{i}$ and $\mathrm{BW}_{i}$ are the average larval abundance and average body weight in each station and strata sampled, respectively; and $B_{2}=A_{i} \times \mathrm{MAI}_{i}$, where $\mathrm{MAI}_{i}$ is the 
average mantle area index (i.e. $\mathrm{MAI}=\mathrm{DML} \times \mathrm{MW}$ $\left[\mathrm{mm}^{2}\right]$ ) according to Sakaguchi et al. (2002), in each station and strata sampled.

(2) The thermohaline and chemical variables in the study area, as in other coastal upwelling systems, are not mutually independent: the cold and salty upwelled waters are relatively nutrient rich and oxygen poor (Álvarez-Salgado et al. 2002). This could lead to models that are redundant and difficult to interpret. To identify candidate variables to introduce into the models, a principal component analysis (PCA) based on the correlation matrix was applied to the hydrographic data: temperature (Temp), salinity (Sal), apparent oxygen utilisation (AOU), nitrate $\left(\mathrm{NO}_{3}\right)$, nitrite $\left(\mathrm{NO}_{2}\right)$, phosphate $\left(\mathrm{PO}_{4}\right)$, silicate $\left(\mathrm{SiO}_{4}\right)$, ammonium $\left(\mathrm{NH}_{4}\right)$ and chlorophyll a (chl a). Three principal components (PCs) interpretable from the environmental point of view were selected. Based on this result, the 3 hydrographic variables highly related with each PC were extracted to compute candidate covariates and their rates of change (see 'Results - Environmental variables').

Akaike's information criterion (AIC) was used to select the optimal model. Large variability in the increase or decrease in abundance and biomass could be more plausible within surveys separated by few days (explained by for example, a high hatching rate in a given day or larval sweeping due to rapid water movement) leading to models with heterogeneity of variance. To take 'time' into account, data were grouped according to the number of days between 2 considered surveys as follows: surveys separated by $\leq 7 \mathrm{~d}$ (Group 1); surveys separated by 7 to 14 d (Group 2); and surveys separated by $>14$ d (Group 3). Models were then fitted using Generalised Least Squares (GLS) that allow errors to have unequal variances for each group. Analyses were performed using $\mathrm{R}$ version 2.6.2 software (R Development Core Team 2008).

\section{RESULTS}

\section{Distribution of the larvae}

In general, octopus larvae were more abundant in the bottom layer and the outer transects (Fig. 3). However, for the purposes of this work we gathered the abundances of all stations and strata sampled during each survey. A detailed spatially explicit analysis will be presented in a separate paper.

\section{Environmental variables}

Three straightforwardly interpretable PCs were extracted by the PCA (Fig. 4). AOU, silicate, phosphate
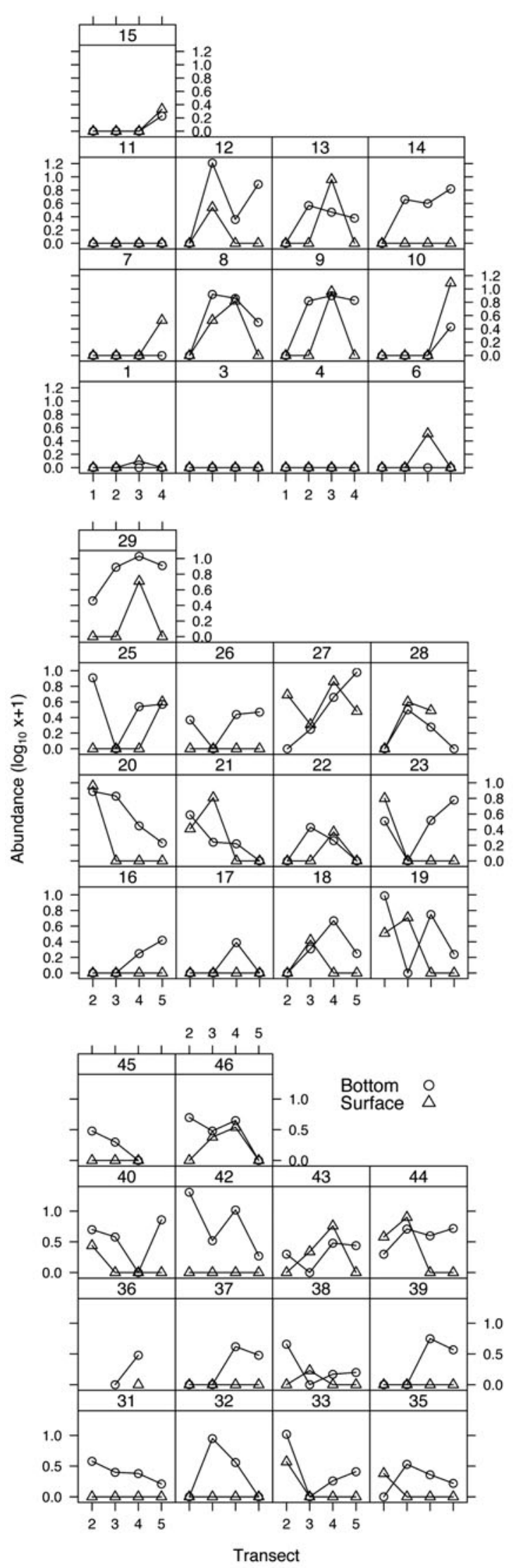

Fig. 3. Octopus vulgaris. Larval abundance $\left(x\right.$, ind. per $\left.10^{3} \mathrm{~m}^{3}\right)$ at surface and bottom in each plankton transect for each survey, grouped by year, as numbered in Table 1 

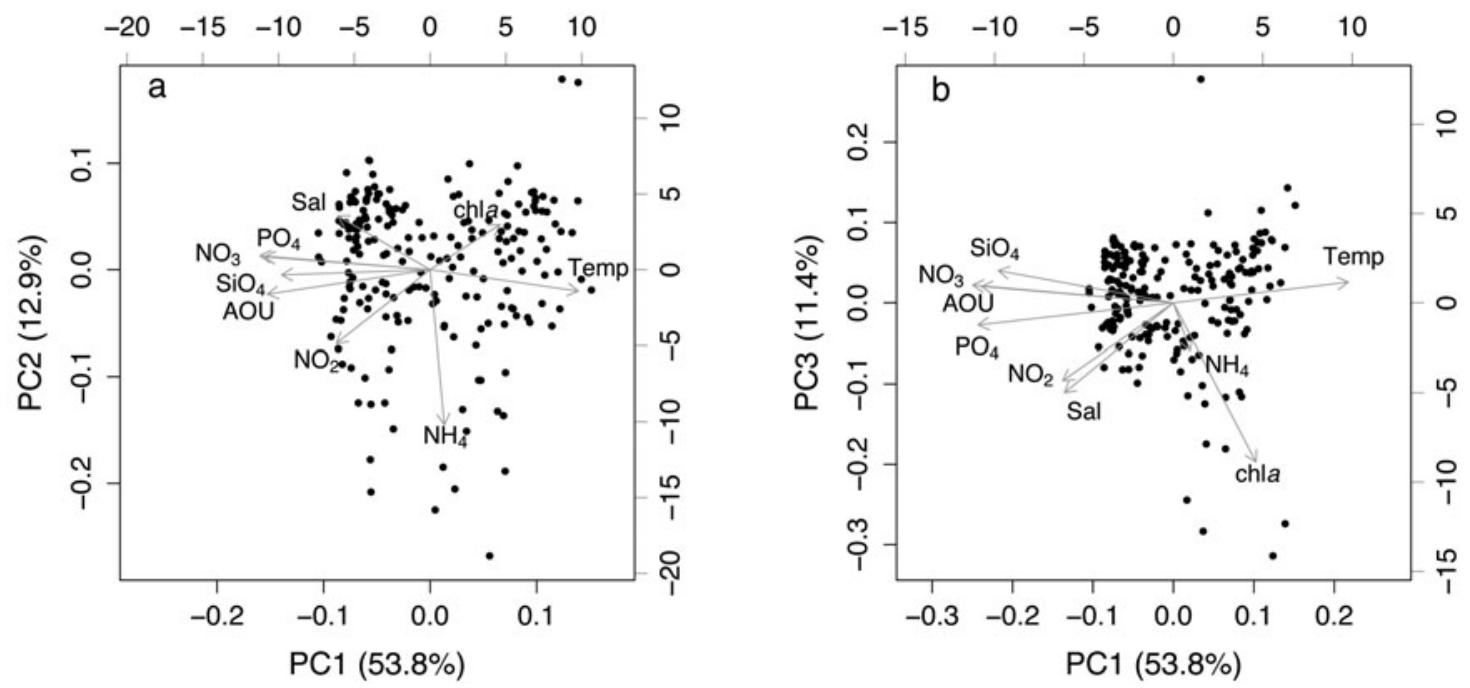

Fig. 4. PCA correlation biplots showing the loadings of each environmental variable (arrows) on the first 3 axes of variability. Points represent the scores of each individual observation. (a) PC1 versus PC2, and (b) PC1 versus PC3. See 'Materials and methods - Statistical analysis' for abbreviations

and, mainly, nitrate have strong negative loadings on PC1, and explain $53.8 \%$ of the variability. These variables are likely to be highly and positively correlated with each other, but negatively correlated with temperature, which has strong positive loading on this PC (Fig. 4a). Therefore, a negative (positive) score of an individual observation on PC1 can be used as an internal upwelling (downwelling) index (Rosón et al. 1995). PC2, which explains $12.9 \%$ of the variability, is highly represented by ammonium, the reduced form of nitrogen involved in fast recycling processes (Eppley \& Peterson 1979). A negative PC2 score indicates in situ regeneration and a positive PC2 score in situ assimilation of nutrient salts (Fig. 4a). Finally, chlorophyll represents PC3, which explains $11.4 \%$ of the variability, pointing to the loss (positive scores) or accumulation (negative scores) of phytoplanktonic biomass (Fig. 4b). Since PC1, PC2, and PC3 show high correlations with nitrate, ammonium and chlorophyll, respectively, we decided to use these 3 hydrographic variables to characterise upwelling/ downwelling, nutrient rege- neration/ consumption, and phytoplankton biomass loss/accumulation, respectively.

Since nitrate, ammonium and chlorophyll were measured at several depths, derived covariates were introduced into the models. For nitrate, 2 covariates were defined: bottom nitrate concentration $\left(\mathrm{NO}_{3 b}\right)$, and average nitrate concentration in the water column
$\left(\mathrm{NO}_{3 i}\right)$; that can be used as an indicator of new production (i.e. the production supported by the nutrients transported by upwelling; Eppley \& Peterson 1979, Álvarez-Salgado et al. 1996). For ammonium, the same covariates were chosen: bottom ammonium concentration $\left(\mathrm{NH}_{4 b}\right)$; and average ammonium concentration in the water column $\left(\mathrm{NH}_{4 i}\right)$; that can be used as an indicator of regenerated production (i.e. the production supported by autochthonous nutrients; Eppley \& Peterson 1979). For chlorophyll, the average chlorophyll concentration in the water column $\left(\mathrm{chl}_{i}\right)$ was chosen, which can be used as an indicator of the retention/loss of phytoplanktonic biomass. Values of the covariates (Table 1) are within the ranges normally found in this area (Álvarez-Salgado et al. 2009), however, some covariates were highly skewed due to the presence of

Table 2. Estimated parameters for the optimal abundance model fitted by generalised least squares (GLS). Dependent variable is the rate of change in abundance (see 'Materials and methods - Statistical analysis'); and covariates are the rates of change in $\mathrm{NO}_{3 i}, \mathrm{NH}_{4 i}$, and $\mathrm{Chl}_{i}$ (water-column averaged nitrate [ $\mu \mathrm{mol}$

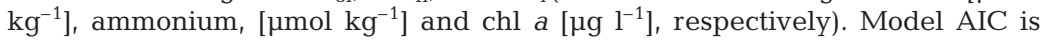
included, and AICs of $B_{1}$ and biomass models $B_{2}$, respectively are also shown in parenthesis.

\begin{tabular}{|lrlrr|}
\hline Parameter & Estimate & \multicolumn{1}{c}{$95 \% \mathrm{CI}$} & \multicolumn{1}{c|}{$t$} & $\mathrm{p}$ \\
\hline Intercept & 0.0018 & $-0.0018,0.0054$ & 1.0034 & 0.3198 \\
$\mathrm{NO}_{3 i}$ & -0.0796 & $-0.1066,-0.0527$ & -5.9104 & $<0.0001$ \\
$\mathrm{NH}_{4 i}$ & -0.0654 & $-0.093,-0.0377$ & -4.7281 & $<0.0001$ \\
$\mathrm{Chl}_{i}$ & -0.0818 & $-0.1089,-0.0547$ & -6.0479 & $<0.0001$ \\
Variance function (different SD per group): $2.1233(1) ; 1(2) ; 0.7702(3)$ \\
$\mathrm{N}=63 ;$ Residual SE $=0.0112$ \\
$\mathrm{AIC}=-308.55(-291.99)_{;}-274.75(-260.81) ;-296.29(-283.17)$ \\
\hline
\end{tabular}


extreme outliers, thus, they were transformed accordingly. All covariates were standardised to $\mathrm{N}(0,1)$ before computing rates of change.

\section{Parametric models}

The AIC criterion used to choose an optimal formulation suggested selecting a model having different variances for each group fitted by GLS. Table 2 summarises the selected model for the larval abundance; and the observed vs. predicted scatter plot derived from the GLS model is presented in Fig. 5. Three covariates should be retained to model both larval abundance and biomass. According to the model, abundance and biomass increases when the concentrations of water column average nitrate $\left(\mathrm{NO}_{3 i}\right)$, ammonium $\left(\mathrm{NH}_{4 i}\right)$ and chlorophyll $\left(\mathrm{Chl}_{i}\right)$ decrease. In addition, as expected, largest residual variance was at Group 1 (i.e. surveys separated by $\leq 7 \mathrm{~d}$ ). It is worth noting, for example, that within $9 \mathrm{~d}$ (Surveys 43 to 46 , Fig. 3) 2 major increases and 1 decrease in abundance took place. Nevertheless, removing these surveys from the analyses lead to the same results (Fig. 5). Finally, major departures from normality or differences in variability in each group were not observed on any plot of the standardized residuals.

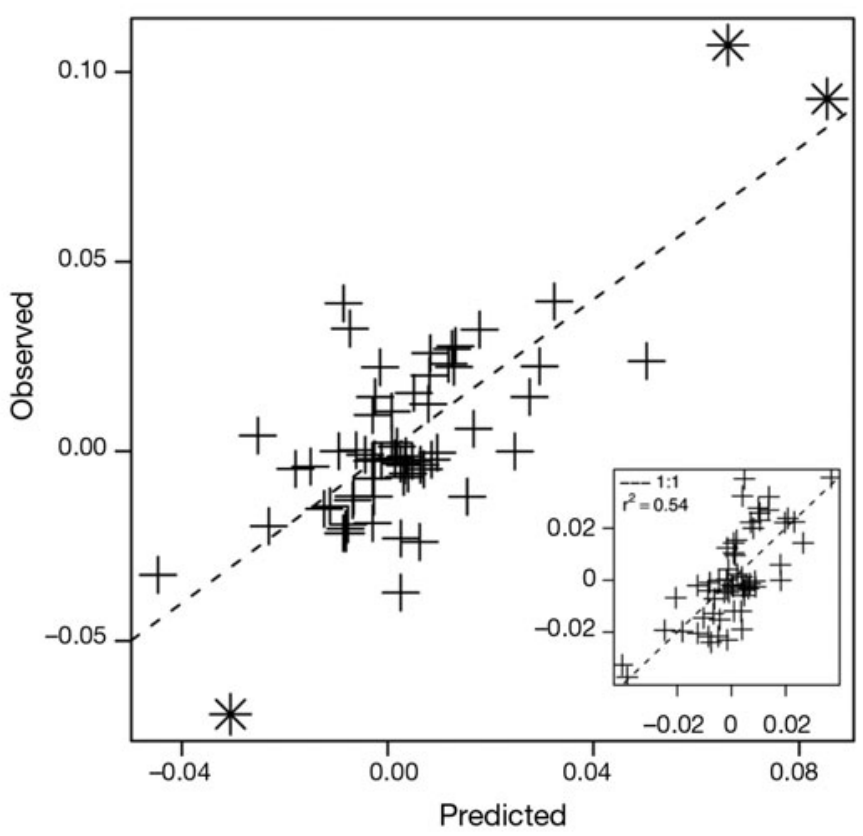

Fig. 5. Observed vs. fitted values for the optimal abundance GLS model summarised in Table 2 (obs $=-0.0005+1.001$ pred; $\left.r^{2}=0.57 ; p=9.75 e-13\right)$. The $1: 1$ line is also shown. The inset shows the observed vs. predicted values for a model (fitted with GLS using the same predictors and different variances for each group, and including 2 interactions, $\mathrm{NO}_{3 i} \times \mathrm{NH}_{4 i}$ and $\mathrm{NO}_{3 i}$ $\times \mathrm{Chl}_{i}$ ) omitting the points indicated with asterisks in the main plot (see 'Results — Models)

\section{DISCUSSION}

Pelagic egg and/or larval phases of many coastal marine organisms undergo dispersal from a spawning source, facing numerous oceanographic features and high mortality before settlement in a different site. Transport of early life stages over a given distance is considered a key factor for population dynamics and their connectivity, genetic structure, and biogeography (Cowen et al. 2007). Mesoscale physical processes, such as upwelling and downwelling, have long been recognised as a cause of variation in larval supply. However, the premise of offshore transport by upwelling cannot be invoked without a specific sampling program (Shanks \& Brink 2005). In this sense, recent studies have suggested different mechanisms that larvae may use to avoid offshore sweeping, including vertical migration (e.g. Ma et al. 2006) or the possession of sensory systems (e.g. smell, Gerlach et al. 2007).

Our results show that Octopus vulgaris average larval abundance and biomass is higher when the nitrate, ammonium and chlorophyll in shelf waters off the Ría Vigo (NW Iberian upwelling system) decrease. A decrease of nitrate is associated with the relaxation, or spin-down phase, of an upwelling episode. It indicates that the nitrate-rich and ammonium-poor Eastern North Atlantic Central Water (ENACW) upwelled from 150 to $200 \mathrm{~m}$ depth to fertilise the rías of the NW Iberian shelf during the spin-up phase of upwelling episodes returns to its original depth (Rosón et al. 1995). A decrease in the water-column ammonium concentration occurs at the early stage of an upwelling relaxation, when the net ecosystem metabolism is favourable to nutrient assimilation rather than regeneration (Álvarez-Salgado et al. 1996). As a result, a net increase of biomass susceptible to be transferred to higher trophic levels occurs. On the other hand, nutrient regeneration is the dominant process during the late phase of upwelling relaxations (Álvarez-Salgado et al. 1996). A decrease in the water-column chlorophyll concentration in the early stage of an upwelling relaxation should be interpreted in this context as an evidence of the transference of phytoplankton biomass to higher trophic levels mediated by zooplankton grazing (Slaughter et al. 2006). Finally, variability appears to be higher when considering short time-periods. All the processes invoked above are driven by the prevailing wind-forcing in the area, but direct relationships with measured upwelling are not immediate, often weak and complex, involving time-lags (e.g. Pérez et al. 2000) and other factors such as topography and materials coming from the coast (e.g. Herrera et al. 2008).

Upwelling relaxation is thought to have 2 effects on larval dynamics: (1) it allows phytoplankton growth and increased concentration at the expense of the nutrients 
upwelled during the dispersive spin-up phase (Zimmerman et al. 1987, Álvarez-Salgado et al. 1996), subsequently allowing zooplankton growth, on which octopus larvae feed; and (2) it reduces larval transport to the adjacent ocean (e.g. Peterman \& Bradford 1987). Therefore, as has been described elsewhere, upwelling does not necessarily lead to offshore transport of larvae. Mechanisms involved in the maintenance of larvae in coastal waters should then be related to the vertical distribution of the larvae in the water column and the surface- and deeper-layer flows. Consistent with these processes we suggest that octopus larvae take advantage of the landward flow of the deeper layer during upwelling events (Souto et al. 2003) in combination with their capacity for performing diel vertical migrations (Otero 2006). In neighbouring Portuguese waters, subjected to similar upwelling regimes, 3D numerical modelling showed that near-shore larval retention is enhanced when simulated Carcinus maenas larvae perform vertical migrations synchronised with the diel cycle (Marta-Almeida et al. 2006). Slow-swimming bivalve larvae can, as well, remain near the coast despite upwelling and downwelling episodes (Shanks \& Brink 2005); and Poulin et al. (2002) demonstrated the nonoffshore transport during upwelling of competent migratory larvae of the gastropod Concholepas concholepas in Chilean coastal waters.

The variability not accounted for by the model may be attributable to other abiotic factors such as water circulation; biotic features, e.g. predation, other interactions or variations in the spawning biomass between and within a year; and/or under sampling of the water column (however, it should be noted that models using only data from the bottom layer gave the same result). On the other hand, part of the variation in the crossshelf abundance is possibly due to along-shore larval drift as a result of the lateral circulation (Souto et al. 2003). However, this effect should be balanced between the southward and northward flows associated with upwelling, downwelling and the topography of the ría, thus, being the abundances consistent in the crossshore direction. Unfortunately, along-shore information on larval abundance is non-existent. Spatial analysis of larvae and the investigation of their origin and hatching dates are beyond the scope of this work and do need complementary approaches such as genetic analysis and/or the use of Individual Based Models (IBMs).

The same model result was obtained when considering the size of the larvae, suggesting that size does not have a significant influence on dispersal, at least at the measured ranges - we assumed that all specimens captured were early hatchlings ( $\leq 10$ day old) according to measured sizes (range 2.48 to $0.96 \mathrm{~mm} \mathrm{DML}$ ) and that each had 3 suckers per arm (Villanueva 1995). Low sample abundances, patchy distribution, and absence of large individuals are common features of cephalopod larval studies (e.g. Zeidberg \& Hamner 2002). These suggest the possible existence of a threshold size determining high movement capacity and/or the ability to avoid the plankton nets by larger specimens.

On a seasonal time-scale, the reproductive cycle of Octopus vulgaris is coupled with the seasonality of wind-driven upwelling in this area (Otero et al. 2007; Fig. 2). The same hatching peak has been observed for a broader area of the western Iberia (Moreno et al. 2009), and even in Japanese waters (Sakaguchi et al. 1999). Apart from the coupling with seasonality, our analysis suggests that high frequency variability in environmental abiotic factors may play an important role in the dynamics of the early life stage of $O$. vulgaris and we believe that this bottom-up effect would affect the population structure of $O$. vulgaris in the NW Iberian upwelling system.

We conclude, therefore, that Octopus vulgaris larvae in Galician waters are more abundant during the relaxation phase of an upwelling event, and that the residual circulation pattern of the ría (dependent on coastal winds), and the migratory behaviour of the larvae, could be responsible for the retention of the larvae near the coast. $O$. vulgaris is a coastal species whose populations tend to be abundant in the waters of the studied area, thus, a non-offshore-swept planktonic phase makes sense. This could point, to some extent, to the occurrence of self-recruitment, a phenomenon more common than previously thought, surprisingly even at relatively small spatial scales (Pineda et al. 2007).

Acknowledgements. This research was funded by the Spanish 'Ministerio de Educación y Ciencia' grant no. REN200202111/MAR, and the 'Xunta de Galicia' grant no. PGIDIT02RMA-C40203PR. We thank the crew of the RV 'Mytilus' for helpful assistance during the cruises. J. Otero was supported by a grant of the Diputación de Pontevedra and an I3P-postgraduate fellowship. Tristan Rouyer provided very useful suggestions on the analyses. Criticism and comments from 4 referees significantly improved the manuscript.

\section{LITERATURE CITED}

Álvarez-Salgado XA, Rosón G, Pérez FF, Figueiras FG, Pazos $Y$ (1996) Nitrogen cycling in an estuarine upwelling system, the Ría de Arousa (NW Spain). I. Short-time-scale patterns of hydrodynamic and biogeochemical circulation. Mar Ecol Prog Ser 135:259-273

Álvarez-Salgado XA, Beloso S, Joint I, Nogueira E and others (2002) New production of the NW Iberian shelf during the upwelling season over the period 1982-1999. Deep-Sea Res I 49:1725-1739

Álvarez-Salgado XA, Figueiras FG, Pérez FF, Groom S and others (2003) The Portugal coastal counter current off NW Spain: new insights on its biogeochemical variability. Prog Oceanogr 56:281-321

Álvarez-Salgado XA, Nieto-Cid M, Gago J, Brea S, Castro CG, Doval MD, Pérez FF (2006) Stoichiometry of the 
degradation of dissolved and particulate biogenic organic matter in the NW Iberian upwelling. J Geophys Res 111: C07017, doi:10.1029/2004JC002473

Álvarez-Salgado XA, Borges AV, Figueiras FG, Chou L (2009) Iberian margin: The rías. In: Liu KK, Atkinson L, Quinoñes R, Talaue-McManus L (eds) Carbon and nutrient fluxes in continental margins. A global synthesis. Springer-Verlag, New York, p 102-119

Amaral V, Queiroga H, Skov M, Paula J (2007) Planktonic availability and settlement of Carcinus maenas megalopae at high temporal resolution in the lower Mira Estuary (SW Portugal). Mar Ecol Prog Ser 348:239-248

Arnáiz R (2006) Los recursos marinos de Galicia. La pesca del pulpo común con nasas en la costa gallega (1999-2004). Xunta de Galicia, Consellería de Pesca e Asuntos Marítimos, Santiago

Barth JA, Menge BA, Lubchenco J, Chan F and others (2007) Delayed upwelling alters nearshore coastal ocean ecosystems in the northern California current. Proc Natl Acad Sci USA 104:3719-3724

Bradbury IR, Laurel B, Snelgrove PVR, Bentzen P, Campana SE (2008) Global patterns in marine dispersal estimates: the influence of geography, taxonomic category and life history. Proc R Soc Lond B Biol Sci 275:1803-1809

Connolly SR, Menge BA, Roughgarden J (2001) A latitudinal gradient in recruitment of intertidal invertebrates in the northeast Pacific Ocean. Ecology 82:1799-1813

Cowen RK, Gawarkiewicz G, Pineda J, Thorrold SR, Werner FE (2007) Population connectivity in marine systems: an overview. Oceanography 20:14-21

$>$ dos Santos A, Santos AMP, Conway DVP (2007) Horizontal and vertical distribution of cirripede cyprid larvae in an upwelling system off the Portuguese coast. Mar Ecol Prog Ser 329:145-155

Eppley RW, Peterson BJ (1979) Particulate organic matter flux and plankton new production in the deep ocean. Nature 282:677-680

Farrell TM, Bracher D, Roughgarden J (1991) Cross-shelf transport causes recruitment to intertidal populations in central California. Limnol Oceanogr 36:279-288

> Gerlach G, Atema J, Kingsford MJ, Black KP, Miller-Sims V (2007) Smelling home can prevent dispersal of reef fish larvae. Proc Natl Acad Sci USA 104:858-863

González AF, Otero J, Guerra A, Prego R, Rocha FJ, Dale AW (2005) Distribution of common octopus and common squid paralarvae in a wind-driven upwelling area (Ria of Vigo, northwestern Spain). J Plankton Res 27:271-277

> Herrera JL, Rosón G, Varela RA, Piedracoba S (2008) Variability of the western Galician upwelling system (NW Spain) during an intensively sampled annual cycle. An EOF analysis approach. J Mar Syst 72:200-217

Hill AE, Hickey BM, Shillington FA, Strub PT, Brink KH, Barton ED, Thomas AC (1998) Eastern ocean boundaries coastal segment. In: Robinson AR, Brink KH (eds) The sea, Vol 11, The global coastal ocean: regional studies and syntheses. Harvard University Press, Massachusetts, p 30-67

Katsanevakis S, Verriopoulos G (2006) Modelling the effect of temperature on hatching and settlement patterns of meroplanktonic organisms: the case of the octopus. Sci Mar 70: 699-708

Ma H, Grassle JP, Chant RJ (2006) Vertical distribution of bivalve larvae along a cross-shelf transect during summer upwelling and downwelling. Mar Biol 149:1123-1138

> Marta-Almeida M, Dubert J, Peliz A, Queiroga H (2006) Influence of vertical migration pattern on retention of crab larvae in a seasonal upwelling system. Mar Ecol Prog Ser $307: 1-19$
Moreno A, dos Santos A, Piatkowski U, Santos AMP, Cabral H (2009) Distribution of cephalopod paralarvae in relation to the regional oceanography of the western Iberia. J Plankton Res 31:73-91

Otero J (2006) Ecología del pulpo común (Octopus vulgaris Cuvier, 1797) en un área de afloramiento costero (Galicia, NE Atlántico). PhD dissertation, University of Vigo, Spain

Otero J, González AF, Sieiro MP, Guerra A (2007) Reproductive cycle and energy allocation of Octopus vulgaris in Galician waters, NE Atlantic. Fish Res 85:122-129

> Otero J, Álvarez-Salgado XA, González AF, Miranda A and others (2008) Bottom-up control of common octopus Octopus vulgaris in the Galician upwelling system, northeast Atlantic Ocean. Mar Ecol Prog Ser 362:181-192

> Pauly D, Christensen V (1995) Primary production required to sustain global fisheries. Nature 374:255-257

> Pérez FF, Álvarez-Salgado XA, Rosón G (2000) Stoichiometry of the net ecosystem metabolism in a coastal inlet affected by upwelling. The Ría de Arousa (NW Spain). Mar Chem 69:217-236

Peterman RM, Bradford MJ (1987) Wind speed and mortality rate of a marine fish, the northern anchovy (Engraulis mordax). Science 235:354-356

Piedracoba S, Álvarez-Salgado XA, Rosón G, Herrera JL (2005) Short-timescale thermohaline variability and residual circulation in the central segment of the coastal upwelling system of the Ría de Vigo (northwest Spain) during four contrasting periods. J Geophys Res 110: C03018, doi:10.1029/2004JC002556

Pineda J, Hare JA, Sponaugle S (2007) Larval transport and dispersal in the coastal ocean and consequences for population connectivity. Oceanography 20:22-39

Poulin E, Palma AT, Leiva G, Narváez D, Pacheco R, Navarrete SA, Castilla JC (2002) Avoiding offshore transport of competent larvae during upwelling events: the case of the gastropod Concholepas concholepas in Central Chile. Limnol Oceanogr 47:1248-1255

> Queiroga H, Cruz T, dos Santos A, Dubert J and others (2007) Oceanographic and behavioural processes affecting invertebrate larval dispersal and supply in the western Iberia upwelling ecosystem. Prog Oceanogr 74:174-191

R Development Core Team (2008) R: a language and environment for statistical computing. R Foundation for Statistical Computing, Vienna

> Rocha F, Guerra A, Prego R, Piatkowski U (1999) Cephalopod paralarvae and upwelling conditions off Galician waters (NW Spain). J Plankton Res 21:21-33

Rosón G, Pérez FF, Álvarez-Salgado XA, Figueiras FG (1995) Variation of both thermohaline and chemical properties in an estuarine upwelling ecosystem: Ría de Arousa; I: Time evolution. Estuar Coast Shelf Sci 41:195-213

Roughgarden J, Gaines S, Possingham H (1988) Recruitment dynamics in complex life cycles. Science 241:1460-1466

Sakaguchi H, Hamano T, Nakazono A (1999) Ocurrence of planktonic juveniles of Octopus vulgaris in eastern IyoNada of Seto Inland Sea, Japan. Bull Jpn Soc Fish Oceanogr 63:181-187

Sakaguchi H, Nakazono A, Akira A (2002) Factors influencing body size of hatchlings, and relationship between fecundity and body weight of female, Octopus vulgaris. Bull Jpn Soc Fish Oceanogr 66:79-83

> Santos AMP, Peliz A, Dubert J, Oliveira PB, Angélico MM, Ré P (2004) Impact of a winter upwelling event on the distribution and transport of sardine (Sardina pilchardus) eggs and larvae off western Iberia: a retention mechanism. Cont Shelf Res 24:149-165 
Shanks AL, Brink L (2005) Upwelling, downwelling, and cross-shelf transport of bivalve larvae: test of a hypothesis. Mar Ecol Prog Ser 302:1-12

Slaughter AM, Bollens SM, Bollens GR (2006) Grazing impact of mesozooplankton in an upwelling region off northern California, 2000-2003. Deep-Sea Res II 53: 3099-3115

Souto C, Gilcoto M, Fariña-Busto L, Pérez FF (2003) Modeling the residual circulation of a coastal embayment affected by wind-driven upwelling: circulation of the Ría de Vigo (NW Spain). J Geophys Res 108(C11), 3340, doi:10.1029/ 2002JC001512

Sweeney MJ, Roper CFE, Mangold K, Clarke MR, Boletzky SV (1992) 'Larval' and juvenile cephalopods: a manual for their identification. Smithson Contrib Zool 513

Takeda R (1990) The distribution of planktonic juveniles of Octopus vulgaris Cuvier in Harima Nada. Suisanzoshoku 38:183-190

UNESCO (1986) Progress in oceanographic tables and standards 1983-1986, work and recommendations of the UNESCO/SCOR/ICES/IAPSO joint panel. UNESCO Tech Pap Mar Sci 50

Editorial responsibility: Paul Snelgrove, St. John's, Newfoundland, Canada
Villanueva R (1995) Experimental rearing and growth of planktonic Octopus vulgaris from hatching to settlement. Can J Fish Aquat Sci 52:2639-2650

Wooster WS, Bakun A, McLain DR (1976) The seasonal upwelling cycle along the eastern boundary of the North Atlantic. J Mar Res 34:131-141

Yannicelli B, Castro LR, Schneider W, Sobarzo M (2006) Crustacean larvae distribution in the coastal upwelling zone off Central Chile. Mar Ecol Prog Ser 319:175-189

Yentsch CS, Menzel DW (1963) A method for the determination of phytoplankton chlorophyll and phaeophytin by fluorescence. Deep-Sea Res 10:221-231

Young RE, Harman RF (1988) 'Larva', 'paralarva' and 'subadult' in cephalopod terminology. Malacologia 29: 201-207

Zeidberg LD, Hamner WM (2002) Distribution of squid paralarvae, Loligo opalescens (Cephalopoda: Myopsida), in the Southern California Bight in the three years following the 1997-1998 El Niño. Mar Biol 141:111-122

Zimmerman RC, Kremer JN, Dugdale RC (1987) Acceleration of nutrient uptake by phytoplankton in a coastal upwelling ecosystem: A modeling analysis. Limnol Oceanogr 32:359-367

Submitted: April 2, 2008; Accepted: March 30, 2009 Proofs received from author(s): June 16, 2009 